\title{
Variation in brand trust scores
}

Received (in revised form): 16th February, 2005

\section{Jenni Romaniuk}

is a senior research fellow at the University of South Australia. She heads the Brand Perceptions/Salience Research programme for the Marketing Science Centre's Research and Development Initiative into marketing, a global research programme supported by companies around the world such as Proctor and Gamble, Unilever, Kraft and General Mills. Her key research areas are: brand salience; brand perceptions; the measurement and interpretation of brand knowledge; and advertising effectiveness. She is also the Editor of the Journal of Empirical Generalisations at www. Empgens.com.

\section{Svetlana Bogomolova}

is a research associate for the Marketing Science Centre at the University of South Australia. Her research focuses on developing empirical generalisations about service quality and brand image measurements.

\begin{abstract}
Brand trust is considered a key aspect of brand relationships, brand personality and brand equity. This paper is an empirical examination of trust scores' variation across 110 brands in 13 markets, ranging from fast moving consumer goods to durables and services. The authors find that generally there is little variation in the trust scores for competing brands that cannot be explained by usage biases in perceptual responses. ${ }^{1,2}$ This lack of variation means that deviations could be detected easily, with ten brands ( 9 per cent) having substantial higher or lower levels of trust. The cases of lower than average trust levels appear to be linked to widespread negative publicity. In contrast it was difficult to see a pattern in the brands with higher than average trust levels. The analysis conducted does demonstrate, however, that by controlling for usage biases, it is possible to evaluate all brands on an equal basis to create benchmarks and to more clearly see deviations. On a cautionary note this research supports suggestions from other authors such as Ehrenberg, Barnard and Scriven $^{3}$ that differences in the perceptions between brands that are simply a reflection of the current size of the brand's user base should not be overplayed.
\end{abstract}

Svetlana Bogomolova Marketing Science Centre, University of South Australia, GPO 2471, Adelaide, SA 5001,

Australia.

Tel: +61 8 83029170; Fax: +61 83020442; e-mail:

Svetlana.Bogomolova@ marketingsciencecentre.com

\section{INTRODUCTION}

It has become a common practice in modern brand management for concepts that are usually associated with personal relationships to be used to describe the interaction between a brand and its customers. ${ }^{4,5}$ With the growth in building brand relationships and customer relationship management (CRM), trust, as a key component of service and relationship quality, has received great attention both in the industry and academia. ${ }^{6,7}$ Elements of 'trustworthiness' have been used as central messages in advertising campaigns. Examples include 'Don't trust your luck, trust RAA Plus' (Royal Automobile Association) and 'Trust is Tampax' (Tampax).

In marketing, it is commonly asserted that to be successful, brands should be positioned such that they are differentiated from competitors. ${ }^{8}$ Such thought influences marketing strategy, measurement, analysis and interpretation. While trust is one such quality cited as a possible aspect for differentiation, this 
idea assumes that brands can vary substantially in their perceived level of trustworthiness, such that one brand is (or could be) more well known for this quality. Contrary to this are claims that trust is a 'hygiene' factor, that all brands must have a certain level of 'trust' in order to be competitive in the market. ${ }^{9}$ This would mean that all competitive brands in the market would display a similar level of trust. It would also mean that 'trust' should be monitored to ensure the brand is similar to other brands in the market on that aspect, but that other attributes should be used to differentiate the brand.

In this paper the authors will test the extent to which brands in the same market differ in the level of trust they are perceived to have by their customers. To do this, they examine perceptions of trust across multiple markets. They also take into account brand size effects, such as the known pattern that brands with more users typically gain higher scores for perceptual responses than brands with fewer users. ${ }^{10}$ Indeed Ehrenberg, Barnard and Scriven ${ }^{11}$ argue that much of the reported differences in scores for image attributes between brands are due to differences in the size of the brands' user base, rather than brand positioning/differentiation. They raised the question of how different competing brands really are, when this brand size effect is accounted for.

The overall objective of this paper is to examine the nature of any variation between brands on the attribute of trust. If considerable variation is evident that is not explainable by brand size effects, this would mean that trust can be used to differentiate brands. If brands were similar in how they are perceived on trust, however, then this would provide more support for the idea of trust as a hygiene factor. The outcome of this research is that it will provide guidelines for interpreting measured perceptions of trust. This study is also important as, unlike typical brand attribute studies, it focuses on one attribute only, but compares across multiple markets. This provides the necessary replications to more fully test the research question.

\section{THEORETICAL BACKGROUND}

The level of trust is thought to be one of the key elements of any relationship or exchange between parties. ${ }^{12-18}$ Morgan and Hunt ${ }^{19}$ defined trust as 'existing when one party has confidence in an exchange partner's reliability and integrity'. This idea is inherent in many conceptualisations $^{20,21}$ where trust is about the confidence that (typically) the buyer has that the manufacturer/seller will live up to any promises and fulfil the requirements of the exchange. Aside from the fulfilment of promises, there is also the idea that trust is generated as an outcome of past interactions, or 'a function of awareness, size, stability, branch availability, service encountered from the company's employees, and in general the pleasantness of dealing with the company'. ${ }^{22}$

The importance of trust as a component of brand-customer and business-to-business relationships and as a component of brand image has been widely discussed in the literature. Extensive research has been devoted to establishing relationships between the brand trust and brand performance metrics, such as loyalty, ${ }^{23,24}$ involvement and brand commitment, ${ }^{25}$ as well as market share. ${ }^{26}$ According to DelgadoBallester, Munuera-Alemán and Yague-Guillen ${ }^{27}$ brand trust has a significant impact on customer commitment, which in turn influences the customers' price tolerance towards the brand. These authors also suggest that overall satisfaction is an antecedent 
of brand trust with trust as a 'cornerstone and one of the most desired qualities in a relationship'. Therefore, trust is considered to be the most important attribute a brand can own. ${ }^{28}$

Trust is considered an asset to the brand that can result in increasing customer loyalty. ${ }^{29}$ For example, along with honesty, fairness or excellence, trust has been called one of the fundamental consumer needs in the financial services market. ${ }^{30}$ In the branding literature, trust is discussed as a possible element for brand differentiation both as an attribute on its own as one of the three aspects of authority, ${ }^{31}$ and as a brand personality trait that contributes to the 'sincerity' dimension. ${ }^{32}$ The relevance of trust has grown with increasing attention on ideas such as brand relationships. ${ }^{33}$ Previously relationship marketing had been the domain of service industries where there was an interpersonal element to the exchange. The idea, however, that consumers have similar relationships with brands in non-service industries (for example, coffee brands are discussed by Fournier $)^{34}$ means that many of the components of interpersonal exchange, such as trust, have been extended to consumer brand exchange.

The extent to which a brand is positioned on an attribute is one metric used to evaluate a brand. Trust (in various forms) is commonly as an attribute incorporated into brand equity/health measures. Competing brands are then compared on their trust scores and brand performance assessed, based on the level of trust relative to competitors.

A brand's 'position' is how it is perceived in the minds of consumers, relative to competitor brands. ${ }^{35}$ Positioning the brand has long been acknowledged as a core marketing activity $^{36}$ and is undertaken with the premise that increased customer loyalty/sales will be the reward. ${ }^{37}$ The cited characteristics of a good position for the brand are (perceived) uniqueness (ie different from competitors), strength and prevalence. ${ }^{38}$ Examples of types of positions include positioning based on the product category, unique benefits of the brand, attitudes/evaluations, price, perceived quality, personality traits, and/or country of origin, for example being local brand. ${ }^{39,40}$

Drawing from the adoption of Associative Network Theories of Memory, ${ }^{41}$ brand knowledge is conceptualised as the set of attributes linked to the brand name in buyer memory. ${ }^{42,43}$ Thus researchers and marketers have examined the extent and nature of the links between brands and attributes in the marketplace to determine the success of marketing activities to position a brand on specific attributes. Brands that have more common and/or stronger links to attributes, compared to other brands, are typically considered to be more successful. From a trust perspective, the key assumption behind this analysis is that brands can (and do) vary considerably in the level of trust that is held in the marketplace and/or among its customer base. That is, brands can be perceived as being more 'trustworthy' than other brands.

Some authors have questioned this. Ambler ${ }^{44}$ considered the correlation between perceived trustworthiness and a brand's market share to be attributed to the time that a company successfully performed in the market, rather than there being real differences in the trust levels of competing brands. Ehrenberg, Barnard and Scriven ${ }^{45}$ go even further and argue that much of what appears to be differences in perceptions of competing brands is in fact just reflecting differences in the size of the brands' user base. 
Perceptual responses are biased by the brands' customers' usage in two ways. First there is a relationship between brand penetration and the responses a brand gains for any attribute. Users are more likely to mention a brand in relation to an attribute, so brands with more users are more commonly mentioned. ${ }^{46}$ Hence, large brands (ie more users) tend to gain more perceptual responses. Even when brand users only are compared, however, (eg responses from users of brand A about brand A with responses from users of brand $\mathrm{B}$ about brand $\mathrm{B}$ ), often a usage bias is still evident. This is referred to as the Double Jeopardy effect $(\mathrm{DJ})^{47-49}$ and is characterised by the idea that small brands are penalised twice; not only do they have fewer users, but those users are less likely to give a positive response about that small brand (compared to users of larger brands). DJ occurs because users of a small brand have a high likelihood of also being users of big brands and therefore they have a chance of mentioning both brands. Big brands, however, have a higher proportion of sole brand users who have a higher propensity to only mention the brand they use. ${ }^{50}$ This results in a statistical selection effect where big brands in total gain more positive responses than small brands, even when the responses for brand users only are compared.

It is possible that many of the reported differences between brands' perceptual scores are simply reporting these brand size (statistical selection) effects. To date no studies have explored this aspect of brand positioning in depth, nor have any tested to see if these patterns hold consistently for brand perceptions of trust across markets. The aim of this research is to fill this gap. It also extends the research of Bird et al. ${ }^{51}$ beyond fast moving consumer goods markets and into durables and services markets.
The following research hypotheses are being tested. Hypotheses 1 and 2 are testing for the presence of user bias patterns in perceptions of trust across markets:

$\mathrm{H}_{1}$ : As per Bird et al., ${ }^{52}$ trust scores will be highly correlated with brand penetration levels.

$\mathrm{H}_{2}$ : As per McPhee, ${ }^{53}$ a DJ effect will be evident such that even when comparing a brand's user base, there will be a high correlation between brand users' perceptions of trust and brand penetration.

Hypotheses $3 \mathrm{a}$ and $3 \mathrm{~b}$ are competing hypotheses about the level of variation between competing brands once the user biases are taken into account. Competing hypotheses, though infrequent in marketing research, are important for knowledge development as they minimise researcher bias. ${ }^{54}$

$\mathrm{H}_{3 \mathrm{a}}$ : Once usage biases are controlled for there will still be brands that differ substantially in the level of trust they have compared to other brands. This hypothesis tests the possibility of being positioned on trust as discussed in the literature..$^{5,56}$

$\mathrm{H}_{3 \mathrm{~b}}$ : Once usage biases are controlled for brands will be similarly rated on levels of trust. This would support the work by Ehrenberg, Barnard and Scriven. ${ }^{57}$

The research method and analysis used to test these hypotheses are now discussed.

\section{RESEARCH METHODOLOGY}

This analysis draws on data collected across a range of markets during the past 
Table 1: Results from the ice cream market $(n=500)$

\begin{tabular}{|c|c|c|c|c|c|c|}
\hline Ice creams & $\begin{array}{l}\text { Penetration } \\
\text { (\% users) }\end{array}$ & $\begin{array}{l}\% \text { total market } \\
\text { associated } \\
\text { with 'trust' }\end{array}$ & $\begin{array}{l}\% \text { users only } \\
\text { associated } \\
\text { with 'trust' }\end{array}$ & $\begin{array}{l}\text { Adjusted } \\
\text { trust\# }\end{array}$ & Deviation & $\begin{array}{l}\text { Mean } \\
\text { absolute } \\
\text { deviation } \\
\text { (MAD) }\end{array}$ \\
\hline Wall's & 41 & 25 & 27 & 19 & 0 & 0 \\
\hline Nestlé & 13 & 21 & 21 & 22 & 2 & 2 \\
\hline Häagen-Dazs & 8 & 9 & 17 & 18 & -1 & 1 \\
\hline Carte D'Or & 4 & 10 & 15 & 18 & -1 & 1 \\
\hline Ben \& Jerry's & 2 & 4 & 16 & 19 & 0 & 0 \\
\hline Average & 14 & 16 & 19 & 19 & - & 1 \\
\hline \multicolumn{2}{|c|}{ Correlations with penetration } & $0.85^{\star *}$ & $0.96^{*}$ & & & \\
\hline
\end{tabular}

DJ coeff. $=(27-16) /(41-2)=0.3$

$\#=\%$ Trust $+\left((\right.$ Average- $\%$ Users $){ }^{*}$ DJ coeff. $)$

${ }^{* *} p<0.01,{ }^{*} p<0.05$

ten years in Australia and the UK. The data cover 110 brands in 13 markets. These markets were skincare products, soups, condiments, personal banking, prepared sauces, ice creams, electronics, computers, cars, spirits, fruit drinks, mineral waters and yoghurt. Markets were chosen based on data availability and to ensure a wide variety of brands in different types of products and service markets. In this paper the authors are not considering trust as a component of relationships between manufacturer/seller and consumers, but rather as one of the aspects of brand image. The task was to determine if customers of a brand trusted that brand (no matter how strong or weak this feeling is or the antecedents to this perception) and how this compared to a similar cohort for other competing brands. The brand attribute 'trust' was measured in the different ways as appropriate to the market. Examples of statements used include 'the brand I trust', 'is trustworthy' and 'is one you can trust to perform'.

Brand/attribute association was measured using a free choice 'pick any' approach. ${ }^{58}$ In all instances attributes were provided to respondents, who were then asked which (if any) brands they associated with the attribute. The 'trust' attribute was included in a series of other attributes. All data were collected as part of typical brand health/image studies in combination with a range of other attributes. Data collection was conducted via telephone or self-completion. Although not prevalent in academia, this approach was chosen for this research as it allows the analysis of data commonly used in industry to ascertain the nature and extent of brand positioning. Using a common type of measure across multiple studies also allows comparisons between different markets.

The usage level of brands was determined by prompting respondents for brands and asking which ones they used. Where respondents could use multiple brands, multiple responses were captured.

\section{RESEARCH PROCEDURE}

First, to illustrate the research procedure, an examination of the ice cream market in the UK is presented. All stages of analysis are described in detail.

Five brands were included in the analysis (Table 1), which are listed in brand penetration order (percentage users as in second column). The proportion of consumers in the overall market associating each of the listed brands with being 'trustworthy' was calculated (third column). The table shows that the figures decline in line with brand penetration levels. For example, Wall's 
An example of DJ scope (electronics market)

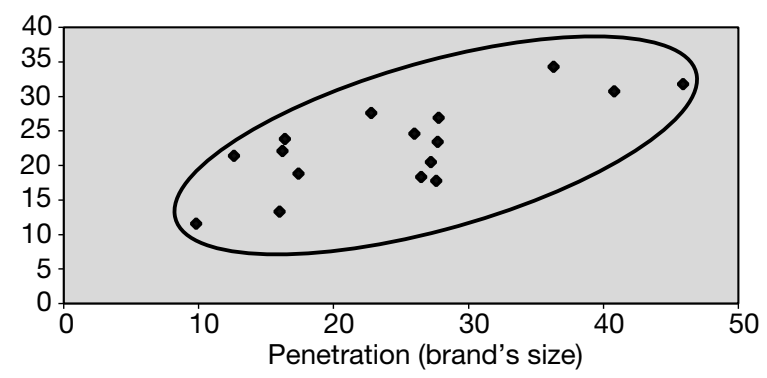

An example of the market where DJ is not evident (computers market)

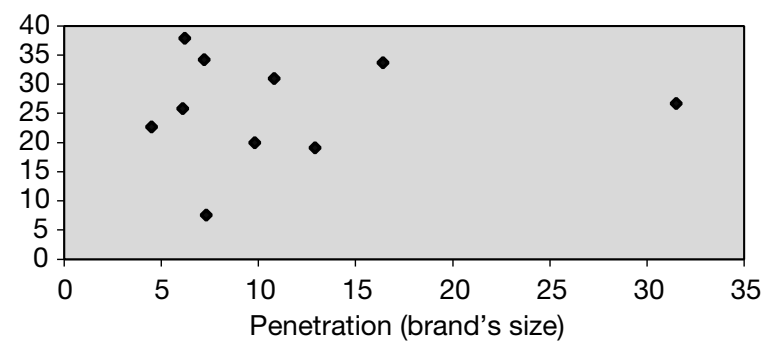

Figure 1 Examples of the markets where DJ pattern was evident (electronics market) and was not evident (computer market).

has the greatest proportion of users (41 per cent) and also has the highest score for the trust (27 per cent). Ben \& Jerry's is the smallest brand ( 2 per cent users) and also has the lowest score for 'trust' (16 per cent). This is quantitatively confirmed using correlation analysis that shows a high and statistically significant correlation $(0.85, p<0.10)$. These results provide support for hypothesis 1 .

Among users of each brand, the proportion of those who associated that brand with the 'trust' attribute was calculated (fourth column). This is again correlated with brand penetration with the resultant correlation coefficient high and statistically significant $(0.96$, $p<0.05)$. These findings confirm existence of DJ effect in the data, supporting hypothesis 2 .

An adjustment for the DJ effect is then made with the slope of the DJ line (as shown in Figure 1). This involves calculating the DJ coefficient as per Barnard and Ehrenberg ${ }^{59}$ using the following equation: the difference between the highest and the lowest score for the attribute divided by the difference between the highest and the lowest penetration within the market. This DJ coefficient is then used to adjust the users' scores as per the following equation: the difference between the average penetration and penetration of the brand multiplying by DJ coefficient plus the brand's 'trust' score. This gives the adjusted trust figures for each brand (fifth column).

The deviation from the average is then calculated (column six) and the mean absolute deviation (MAD) (column seven). The average of this is the measure of variance between brands in the marketplace. The individual brand deviations are used to isolate outliers that might be of managerial relevance. The 
Table 2: Correlations with penetration

\begin{tabular}{|c|c|c|c|}
\hline Market name & $\begin{array}{l}\text { Number of } \\
\text { brands }\end{array}$ & $\begin{array}{l}\text { Total market } \\
\text { correlation coefficient }\end{array}$ & $\begin{array}{l}\text { User correlation } \\
\text { coefficient }\end{array}$ \\
\hline \multicolumn{4}{|l|}{ High correlations } \\
\hline Soups & 6 & $0.81^{*}$ & $0.82^{*}$ \\
\hline Condiments & 12 & $0.91^{*}$ & $0.71^{\star}$ \\
\hline Ice creams & 5 & $0.85^{\star \star}$ & $0.96^{*}$ \\
\hline Yogurts & 6 & $0.85^{\star}$ & $0.72^{\star \star}$ \\
\hline Ready made sauces & 9 & $0.87^{\star}$ & $0.82^{\star}$ \\
\hline Skin care products & 8 & $0.87^{*}$ & $0.63^{\star *}$ \\
\hline Electronics & 16 & $0.85^{\star}$ & $0.75^{\star}$ \\
\hline Mineral waters & 7 & $0.76^{*}$ & $0.77^{\star}$ \\
\hline Spirits & 7 & $0.69^{\star \star}$ & $0.59^{\star \star}$ \\
\hline \multicolumn{4}{|l|}{ Low correlations } \\
\hline Personal banking & 7 & $0.88^{*}$ & 0.04 \\
\hline Fruit and vegetable drinks & 6 & $0.90^{\star}$ & 0.35 \\
\hline Automobiles & 9 & 0.50 & -0.22 \\
\hline Computers & 10 & 0.32 & 0.08 \\
\hline
\end{tabular}

${ }^{*} p<0.05 ;{ }^{* *} p<0.10$

size of the MAD and the range of the deviations give an indication of variance. A MAD of 1 percentage point (pp) and a range from +2 to -1 suggest very little variance between brands once the usage bias is taken into account.

Thus the authors would conclude that, in line with Ambler ${ }^{60}$ and Ehrenberg, Barnard and Scriven, ${ }^{61}$ in this market no ice cream brand is perceived as being substantively more (or less) trustworthy than any other. Any apparent differences in the overall responses brands obtain can be explained by differences in the number of people who use the brand.

The same analysis was conducted over 12 further markets. The results for each of the hypotheses are discussed separately.

Hypothesis 1 referred to the correlation between the brand penetration levels and the proportion of the market that state the perception that the brand is trustworthy. The correlations (shown in Table 2) were high and statistically significant for 11 out of 13 markets. This suggests support for hypothesis 1 , namely that there is a usage bias whereby brands with more users gain higher response levels for trust than brands with fewer users, as per Bird et al. ${ }^{62}$ Markets with low correlation were typically characterised by a large number of small brands where considerable variation in trust scores was evident. Therefore, in markets with high brand penetrations, there will be a strong correlation between brand penetration and brand trust. In markets with a large number of brands with lower brand penetrations (ie below 10 per cent), however, these smaller brands can vary in their trust level and possibly gain 'excess' trust. This effect is not driven by the nature of particular markets but just by a competition structure of some markets (ie many small brands).

There was also a considerable support for hypothesis 2 (the existence of a DJ effect), with high correlations between the responses each brand obtained from its users and the brand penetration. In two markets, personal banking and fruit and vegetable drinks, there was a high correlation between brand penetration and trust but a low correlation with user perceptions of trust. This was due to a lack of variation between brands (three brands at 43 per cent). Automobiles and computers again have low correlations, again due to considerable variation in the trust ratings of the smaller brands (as noted during hypothesis 1 testing). To 
Table 3: Variation in brand trust scores

\begin{tabular}{lclll}
\hline Market name & $\begin{array}{l}\text { Number of } \\
\text { brands }\end{array}$ & $\begin{array}{l}\text { Average trust } \\
\text { score }\end{array}$ & $\begin{array}{l}\text { Average user } \\
\text { trust score }\end{array}$ & MAD \\
\hline Automobiles & 9 & 29 & 42 & 4 \\
Soups & 6 & 28 & 33 & 4 \\
Condiments & 12 & 24 & 33 & 4 \\
Ready made sauces & 9 & 21 & 27 & 3 \\
Skin care products & 8 & 19 & 31 & 6 \\
Electronics & 16 & 18 & 23 & 4 \\
Personal banking & 7 & 18 & 44 & 5 \\
Spirits & 7 & 17 & 28 & 7 \\
Fruit and vegetable drinks & 6 & 16 & 30 & 1 \\
Ice creams & 5 & 11 & 19 & 3 \\
Mineral waters & 7 & 10 & 19 & 7 \\
Yogurts & 6 & 13 & 20 & 5 \\
Computers & 10 & 19 & 28 & 5 \\
Average & 8 & & 30 & \\
\hline
\end{tabular}

illustrate the patterns an example of the difference in markets where the DJ effect is present (electronics) or not present (computers) is provided, as shown in Figure 1.

To quantify the variation in trust scores across competing brands in the market, the MAD for each market was calculated. The MAD's ranged from $1 \mathrm{pp}$ to 9pp, however in nine out of 13 markets, variation was $4 \mathrm{pp}$ or less. For the remaining five markets, much of the variation can be explained by specific brand deviations within the market (discussed in the next section) rather than being a market issue. Therefore, typically, managers can expect that there will be less than $5 \mathrm{pp}$ variation between brands in a market that cannot be explained by brand size.

\section{BRAND DEVIATIONS}

Overall, across 110 brands, there were eight brands with greater than $10 \mathrm{pp}$ variation in trust scores identified. These were concentrated in four of the 13 markets. Interestingly, four of the eight large deviations were negative, with brands scoring about 10 per cent lower than average for trust. These negative deviations seem to be linked to large amounts of negative publicity. For example, Sunny Delight, -19pp (fruit drinks market) had considerable negative publicity from consumer and health groups 'who argued that it was low in fruit juice and high in sugar and other ingredients, including vegetable oil and thickeners $^{63}$ or Bacardi, -19pp (spirits) was involved in a conflict with a Cuban company about the rights for the rum brand 'Havana Club', and prior to the data collection the conflict had a wide media exposure, which resulted in some negative connotations with the brand Bacardi. ${ }^{64}$ These examples suggest that in some cases it might be necessary for a brand to take remedial action to improve its image by focusing on trust to get back to the level that is expected for it, based on its size and market. The standardisation of brand trust scores to control for usage biases allows the extent of these problems to be identified. It also enables the 'normal' value to be established.

The remaining five large brand deviations were positive, scoring over $10 \mathrm{pp}$ higher than average trust level in their markets. Examples of high trust brands were Oil of Ulay (+14pp) (skin care market), which is a large brand with considerable tenure in the market, 
likewise, Compaq $(+12 p p)$ in the computer market. This coincides with Ford's ${ }^{65}$ claim that trust was an outcome of past interactions, and Ambler's ${ }^{66}$ idea that trust is linked to the amount of time the brand has performed successfully in the market. It should be noted that typically the brand with more users did not deviate on being more trustworthy than would be expected for a brand of its size. So the correlation between positive deviations on trust levels and market share was not evident. Therefore it is impossible to conclude from crosssectional studies if the trust perceptions came before or after usage.

On the other hand, it is also possible that such high trust scores could be a result of a successful advertising or positioning campaign to build brand image on trust. In any event, the lack of variation within any market would make successful positioning easy to detect. Deviations do stand out considerably from the remaining brands in the marketplace, once user biases are controlled for. At category level, the average level of trust across markets was also quite similar, with the majority of markets having an average trust level of about 20 per cent (total market score includes responses from users and non-users). The average response level for an attribute is an indicator of the prototypicality of an attribute, or the degree to which it contributes to category membership. ${ }^{67,68}$ This supports the claim of Ambler ${ }^{69}$ that trust is a hygiene factor, as it suggests that trust has a similar contribution across markets.

\section{DISCUSSION}

This research generally supports the contention of Ambler ${ }^{70}$ and Ehrenberg, Barnard and Scriven ${ }^{71}$ that trust is not a factor where brands exhibit considerable variation. The high response levels in each market show that brand trust was of relevance to users, however trust is more like a 'hygiene' factor in that all brands have to have a certain level of trust to be competitive in the market. Or, as put by Bayne, ${ }^{72}$ it is 'a value that is expected'. In general, customers of one brand 'trust' this brand approximately to the same extent, as customers of the competitors' brands trust the brands they use. This was the general pattern evident in the 14 quite different markets tested in this research. There was also generalised support for the findings of Bird et al. ${ }^{73}$ that the brand perceptual responses a brand gains are highly correlated with the brand penetration and that there is a DJ pattern when brand user responses are compared. ${ }^{74-76}$ Even the three markets where there were low correlations between brand trust scores (total market and users only) and penetration, the level of variation between brands was still relatively small.

There are exceptions to this, however, where brands did deviate both positively and negatively. Negative deviations seemed to be linked to highly publicised negative issues. Positive deviations were more difficult to explain without individual brand histories. It can be concluded however that deviations will be noticeable, because once the usage bias is controlled for, brands do not typically differ on trust and market norms are easily established. This paper makes an important contribution to brand measurements by detailing how to detect and control for the Double Jeopardy effect.

The findings of this paper also have important implications for brand managers and academics working in the area of brand image. The study suggests that rarely was one brand perceived as being more or less trustworthy than other brands once the 'brand size' effects were controlled for. 
The fact that the DJ bias was evident in most of the markets emphasises that controlling for number of users/penetration is an essential part of the analysis process. Otherwise there is a danger of underreporting how widely the beliefs are held, a point also made by Barnard and Ehrenberg. ${ }^{77}$ The findings of this research into trust perceptions suggest that other perceptions should be examined across markets to see if a similar consistency across brands exists, as suggested by Ehrenberg, Barnard and Scriven. ${ }^{78}$ If this was a consistent pattern across all attributes and markets then it may lead to a reinterpretation of brand perceptions and a revision of benchmarks and expectations for competing brands.

\section{LIMITATIONS AND FUTURE RESEARCH}

This research examined one aspect of the brand ie perceptions of trust. A key limitation is that only one form of measurement (ie pick any brand from a list) indicating if a brand was trustworthy has been used in this research. It can be argued that this measure is not a sensitive enough instrument for capturing such an intangible attribute as 'trust'. Therefore the authors recommend future research to test alternative measures, such as scales, to see if the same lack of variation exists. This would allow further testing to see if the lack of variation identified in this research is simply a function of the measurement approach.

Key areas of future research lie in applying the same approach to other brand attributes that brands can position or differentiate themselves on such as, for example, position on exceptional service or low price. Further comparison of such research results could allow determination of the expected level for different attributes within specific markets.

\section{References}

1 Bird, M., Channon, C. and Ehrenberg, A. S. C. (1970) 'Brand image and brand usage', Journal of Marketing Research, Vol. 7, August, pp. 307-314.

2 McPhee, W. N. (1963) 'Formal theories of mass behaviour', The Free Press of Glencoe, New York.

3 Ehrenberg, A. S. C., Barnard, N. and Scriven, J. (1997) 'Differentiation or salience', Journal of Advertising Research, Vol. 37, No. 6, November-December, pp. 7-14.

4 Delgado-Ballester, E., Munuera-Alemán, J. L. and Yague-Guillen, M. J. (2003) 'Development and validation of a brand trust scale', International Journal of Market Research, Vol. 45, 1, pp. 35-54.

5 Fournier, S. (1988) 'Consumers and their brands: Developing relationship theory in consumer research', Journal of Consumer Research, Vol. 24, March, pp. 343-373.

6 Clout, J. (2001) 'Winning trust is the key to getting ahead', Financial Review, 29th August.

7 Coulter, K. S. and Coulter, R. A. (2002) 'Determinants of trust in a service provider: The moderating role of length of relationship', Journal of Services Marketing, Vol. 16, No. 1, pp. 35-50.

8 Ries, A. and Trout, J. (2001) 'Positioning: The battle for your mind', McGraw Hill, New York.

9 Ambler, T. (1997) 'Do brands benefit consumers?', International Journal of Advertising, Vol. 16, No. 3.

10 Bird, Channon and Ehrenberg (1970) op. cit.

11 Ehrenberg, Barnard and Scriven (1997) op. cit.

12 Chaudhuri, A. and Holbrook, M. B. (2002) 'Product-class effects on brand commitment and brand outcomes: The role of brand trust and brand affect', Brand Management, Vol. 10, No. 1, pp. 33-58.

13 Delgado-Ballester, Munuera-Alemán and Yague-Guillen (2003) op. cit.

14 Dwyer, F. R., Schurr, P. H., and Oh, S. (1987) 'Developing buyer-seller relationships', Journal of Marketing, Vol. 51, April, pp. 11-27.

15 Gundlach, G. T. and Murphy, P. E. (1993) 'Ethical and legal foundations of relational marketing exchanges', Journal of Marketing, Vol. 57, October, pp. 35-46.

16 Moorman, C., Zaltman, G. and Deshpandé, R. (1992) 'Relationships between providers and users of market research: The dynamics of trust within and between organizations', Journal of Marketing Research, Vol. 29, August, pp. 314-328.

17 Morgan, R. and Carter, I. (1998) 'Measuring brand equity - A consumer-led approach', Admap, July.

18 Morgan, R. M. and Hunt, S. D. (1994) 'The commitment-trust theory of relationship marketing', Journal of Marketing, Vol. 58, July, pp. 20-38.

19 Ibid.

20 Gundlach and Murphy (1993) op. cit.

21 Moorman, Zaltman and Deshpandé et al. (1992) op. cit. 
22 Ford, R. (1990) 'Insurance advertising in the 1990s', Admap, June.

23 Delgado-Ballester, Manuera-Aleman and Yague-Guillen (2003) op. cit.

24 Morgan and Carter (1998) op. cit.

25 Chaudhuri and Holbrook (2002) op. cit.

26 Ambler (1997) op. cit.

27 Delgado-Ballester, Munuera-Alemán and Yague-Guillen (2003) op. cit., p. 35.

28 Delgado-Ballester, E. and Munuera-Alemán, J. L. (2001) 'Brand trust in the context of consumer loyalty', European Journal of Marketing, Vol. 35, Nos $11 / 12$, pp. $1238-1258$.

29 Ambler (1997) op. cit.

30 Bayne, T. (1999) 'Financial frogs and global princes', Admap, July.

31 Morgan, R. P. (1999-2000) 'A consumer-orientated framework of brand equity and loyalty', Journal of the Market Research Society, Vol. 42, No. 1, pp. 65-78.

32 Aaker, J. L. (1997) 'Dimensions of brand personality', Journal of Marketing Research, Vol. 34 August, pp. 347-356.

33 Fournier (1988) op. cit.

34 Ibid.

35 Stanton (1978) as cited in Sarel, D. (1980) 'Product positioning - A reassessment', in Lamb, C. W. and Dunne, P. M. (eds) 'Theoretical developments in marketing', American Marketing Association, pp. 116-119.

36 Aaker, D. A. and Shansby, G. (1982) 'Positioning your product', Business Horizons, Vol. 25, pp. 56-62.

37 Ries, A. and Trout, J. (1986) 'Positioning: The battle for your mind', McGraw-Hill Inc., New York.

38 Aaker, D. A. (1991) 'Managing brand equity: Capitalizing on the value of a brand name', The Free Press, New York.

39 Aaker, D. and Myers, J. G. (1987) 'Advertising management', 3rd edn, Prentice-Hall, New Jersey.

40 Holden, S. J. S. (1993) 'Understanding brand awareness: Let me give you a c(l)ue!', Advances in Consumer Research, Vol. 20, pp. 383-388.

41 Anderson, J. R. and Bower, G. H. (1979) 'Human associative memory', Lawrence Erlbaum, Hillsdale N.J.

42 Keller, K. L. (1993) 'Conceptualizing, measuring, and managing customer-based brand equity', Journal of Marketing, Vol. 57, January, pp. 1-22.

43 Keller, K. L. (2003) 'Brand synthesis: The multidimensionality of brand knowledge', Journal of Consumer Research, Vol. 29, March, pp. 595-601.

44 Ambler (1997) op. cit.

45 Ehrenberg, Barnard and Scriven (1997) op. cit.

46 Bird, Channon and Ehrenberg (1970) op. cit.
47 Chaudhuri, A. (1995) 'Brand equity or double jeopardy', Journal of Product \& Brand Management, Vol. 4, No. 1, pp. 26-32.

48 Ehrenberg, A. S. C., Goodhardt, G. J., and Barwise, P. T. (1990) 'Double jeopardy revisited', Journal of Marketing, Vol. 54, July, pp. 82-91.

49 McPhee (1963) op. cit.

50 Bird, Channon and Ehrenberg (1970) op. cit.

$51 \mathrm{Ibid}$.

52 Ibid.

53 McPhee (1963) op. cit.

54 Armstrong, J. S., Brodie, R. J., and Parsons, A. G. (2001) 'Hypothesis in marketing: Literature review and publication audit', Vol. 12, pp. 171-187.

55 Delgado-Ballester and Munuera-Alemán (2001) op. cit.

56 Morgan (1999-2000) op. cit.

57 Ehrenberg, Barnard and Scriven (1997) op. cit.

58 Barnard, N. R. and Ehrenberg, A. S. C. (1990)

'Robust measures of consumer brand beliefs', Journal of Marketing Research, Vol. 27, November, pp. 477-487.

59 Ibid.

60 Ambler (1997) op. cit.

61 Ehrenberg, Barnard and Scriven (1997) op. cit.

62 Bird, Channon and Ehrenberg (1970) op. cit.

63 Teather, D. (2004) 'P\&G offloads controversial Sunny Delight', The Guardian, 2nd April http://www.guardian.co.uk/business/story/ $0,3604,1184288,00 . h t m l$

64 BBC News (2002) 'WTO intervenes in Havana rum clash', 2nd January, http://news.bbc.co.uk/ 1/hi/business/1739589.stm.

65 Ford (1990) op. cit.

66 Ambler (1997) op. cit.

67 Romaniuk, J. and Sharp, B. (2000) 'Using known patterns in image data to determine brand positioning', International Journal of Market Research, Vol. 42, Issue 2, Spring/Summer, pp. 219-230.

68 Ward, J. C., Bitner, M. J., and Barnes, J. (1992) 'Measuring the prototypicality and meaning of retail environments', Journal of Retailing, Vol. 68, No. 2, Summer, pp. 194-220.

69 Ambler (1997) op. cit.

70 Ibid.

71 Ehrenberg, Barnard and Scriven (1997) op. cit.

72 Bayne (1999) op. cit., p. 3.

73 Bird, Channon and Ehrenberg (1970) op. cit.

74 Chaudhuri (1995) op. cit.

75 Ehrenberg, Goodhardt and Barwise (1990) op. cit.

76 McPhee (1963) op. cit.

77 Barnard and Ehrenberg (1990) op. cit.

78 Ehrenberg, Barnard and Scriven (1997) op. cit. 